\title{
Prof. Dr. med. Dr. h. c. mult. Manfred Göthert (1939-2019)
}

\author{
Barbara Malinowska ${ }^{1} \cdot$ Edmund Przegaliński $^{2} \cdot$ Eberhard Schlicker $^{3}$
}

Published online: 20 January 2020

(c) The Author(s) 2020

\begin{abstract}
"Being a scientist is not only a profession. It is a lifestyle".
\end{abstract}

Prof. Manfred Göthert, an eminent German pharmacologist and a great friend of Polish scientists, passed away on June $28,2019$.

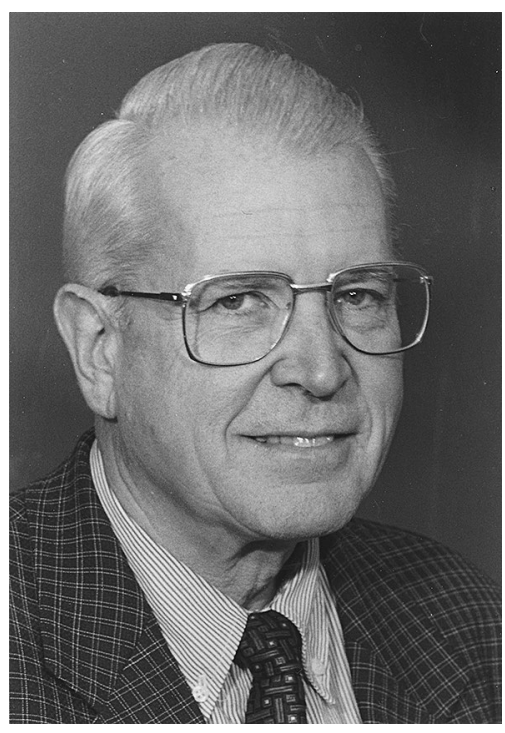

Prof. Göthert was born on 12 December 1939 in Braunschweig (Germany). He attended primary and secondary

Barbara Malinowska

bmalin@umb.edu.pl

1 Department of Experimental Physiology

and Pathophysiology, Medical University of Białystok, Białystok, Poland

2 Institute of Pharmacology, Polish Academy of Sciences, Kraków, Poland

3 Department of Pharmacology and Toxicology, University of Bonn, Bonn, Germany schools in Lindau (Germany), Rognac (France) and again in Germany in Hildesheim and Braunschweig. From 1959 to 1965 he studied medicine at the Universities of Hamburg, Freiburg and Göttingen in Germany and of Innsbruck and Wien in Austria. During his study in Innsbruck he met his future wife Irmgard Karin ("Inka") with whom he had 3 sons and 8 grandchildren. Because of his wife's private practice in Hamburg his family lived permanently in this city and Prof. Göthert travelled from Essen or Bonn (where he worked, see below) to Hamburg on Friday afternoon and returned to work on Monday morning. No wonder that he entitled his autobiography "Life in movement as a scientist" [1].

Prof. Manfred Göthert published nearly 300 original and review publications. The great importance of his pioneering observations is reflected by more than 10,000 quotations and a Hirsch Index of 52. The scientific career of Prof. Göthert was associated with Institutes of Pharmacology or of Pharmacology and Toxicology at three universities: in Hamburg (1967-1978), Essen (1978-1985) and Bonn (1985-2006, where he was the director of the institute).

In Hamburg, he worked as postdoctoral fellow first in the group of Günther Malorny about carbon monoxide toxicology. Then, he switched to the laboratory of Hans-Friedrich Benthe where he worked on cardiovascular pharmacology. He studied effects of general anaesthetics and ethanol on the release of noradrenaline from peripheral sympathetic nerves in the rabbit heart and of catecholamines from the bovine adrenal medulla. To evoke noradrenaline/catecholamine release, he used electrical stimulation, $\mathrm{K}^{+}$depolarisation, tyramine and/or acetylcholine and serotonin (5-HT) activating ligand-gated ion channels (nicotinic and 5- $\mathrm{HT}_{3}$ receptors, respectively). He was the first to identify the latter two receptors as sites of action of ethanol and general anaesthetics. The above pioneering observations allowed him to complete his habilitation thesis already in 1971; he received the title of a professor in 1976.

In Essen, where Eberhard Schlicker joined his group, he identified the 5-HT autoreceptor in the rat brain simultaneously with, but independent from, Maurizio Raiteri. In cooperation with Günter Engel from Sandoz (now Novartis) he 
could show that the autoreceptor is a $\mathrm{r} 5-\mathrm{HT}_{1 \mathrm{~B}}$ receptor. Later it became evident that the rat is not a good model for the human brain and in cooperation with Derek N. Middlemiss from SmithKline Beecham (now GlaxoSmithKline) he could prove that the autoreceptor in human brain is $\mathrm{h} 5-\mathrm{HT}_{1 \mathrm{~B}}$ (the species homologues have a similar amino acid sequence but markedly different pharmacological properties). Moreover, Prof. Göthert was the first to identify presynaptic somatostatin and ACTH receptors, which occur on central and peripheral noradrenergic neurones, respectively.

In Bonn, where Gerhard J. Molderings and Klaus B. Fink joined his group, numerous types of facilitatory and inhibitory heteroreceptors on peripheral noradrenergic neurones were described, most of them in human tissues. The human $\alpha_{2}$-autoreceptor was classified as $\alpha_{2 A}$-subtype and the $\beta_{2}$-autoreceptor was shown to lead to increased formation of angiotensin II which, in turn, facilitates noradrenaline release via presynaptic $\mathrm{AT}_{1}$ receptors. With respect to central monoaminergic neurones presynaptic histamine $\mathrm{H}_{3}$ and cannabinoid $\mathrm{CB}_{1}$ receptors were identified for the first time.

The effect of ethanol and general anaesthetics on nicotinic and $5-\mathrm{HT}_{3}$ receptors was further elaborated in three respects. Studies showed (1) that ethanol also interacts with NMDA receptors and (2) that a fourth type of ionotropic receptor, the AMPA receptor, may be involved in the effect of the anticonvulsant drug gabapentin. (3) Nicotinic and 5- $\mathrm{HT}_{3}$ receptors proved to be possible targets also for cannabinoids. Part of the latter studies was carried out in cooperation with Barbara Malinowska. In this context the elucidation of the complex mechanism of action of the endocannabinoid anandamide in the cardiovascular system of the rat has to be mentioned as well.

Prof. Göthert also became interested in molecular aspects of 5- $\mathrm{HT}_{3}$ and other 5-HT receptor subtypes. Heinz Bönisch (previous coworker of Ullrich Trendelenburg in Würzburg and called to Bonn) along with his coworkers Michael Brüss and Martin Barann contributed molecular biological and electrophysiological techniques. Thus, the $\mathrm{F} 124 \mathrm{C}$ variant of the human 5-HT ${ }_{1 \mathrm{~B}}$ receptor is associated with an increased affinity of ligand binding, $G$ protein coupling and second messenger formation. On the other hand, the $\mathrm{R} 344 \mathrm{H}$ variant of the human 5- $\mathrm{HT}_{3 \mathrm{~A}}$ receptor and the $\mathrm{P} 279 \mathrm{~L}$ variant of the human $5-\mathrm{HT}_{7 \mathrm{~A}}$ receptor show a decrease in receptor binding and intracellular signal transduction, respectively.

Prof. Göthert's outstanding scientific achievements were appreciated by various international scientific communities. He was president of the Federation of the European Pharmacological Societies (EPHAR; 2004-2006) and of the German Society of Experimental and Clinical Pharmacology and Toxicology (DGPT; 1997-1999) and vice president of the International Society of Serotonin Research (1994-1998). Moreover, he served as dean of the Medical Faculty, University of Bonn (1998-2000), managing editor of Naunyn-Schmiedeberg's Archives of Pharmacology (1995-2002) and advisory editor of British Journal of Pharmacology, Pharmacological Reports, Fundamental and Clinical Pharmacology and Neurochemistry International. In addition, Prof. Göthert was the organizer or co-organizer of the 13th congress of the International Union of Basic and Clinical Pharmacology (IUPHAR; München, 1998), the 4th EPHAR congress (Porto, 2004) and of conferences dedicated to vascular neuroeffector mechanisms (Bonn, 1990), serotonin (Frankfurt, 1989; Bonn, 1989; Porto, 2004) and imidazolines (Bonn, 1998).

Prof. M. Göthert was honoured for his scientific achievements by the election as a member of the German National Academy Leopoldina and the conferment of the honorary membership of the DGPT and the International Society for Serotonin Research.

Prof. M. Göthert named himself a "German European" $[1,2]$. He said during the ceremony when he received the title of a Doctor honoris causa of the Medical University of Białystok [2]: "I was born in 1939, the year in which Nazi Germany began the Second World War by attacking Poland. This war brought unspeakable sorrow to your country. This cannot be forgotten and cannot be forgiven.

When considering this, it appears as a miracle that a German scientist can receive the highest honour from a Polish university. How could this become possible? Basically, the remarkable and memorable efforts of individuals, who formerly were members of hostile armies during the Second World War, decisively contributed to it. It was 30 years ago when these persons started a cooperation between Polish and German pharmacologists. I mention only two names, Ullrich Trendelenburg from Würzburg and Jerzy Maj from Cracow. From the viewpoint of my own curriculum vitae this was a logical and very necessary step. I had lived as a child in France for two years - very shortly after the second World War had come to an end. The only experience which my family made was to be respected as individuals and to experience friendship - my parents with adults and I myself with my schoolmates. Thus, the basis of my present thinking was lived as a German in Europe or - in other words - as a "German European".

Better understanding between two countries is certainly not only a matter of politicians, but - as I already mentioned - individual scientists made successful efforts towards the development of good relations between former enemies - Poles and Germans. They promoted contacts which grew to become mutual respect, cooperation and finally friendship. These pioneers paved the way to make it much easier for persons of my generation to develop friendship across the 
border between our countries. Generally speaking, it is easier for scientists to have good relations with colleagues from other countries - irrespective of obstacles in history and actual political conditions. Science has been and will be international, because scientific topics arising are identical all over the world."

Professor Göthert always spoke very warmly about Polish pharmacologists, he constantly stressed the importance of the long-standing cooperation between German and Polish pharmacologists and always, despite his many responsibilities, found time for talks and discussions with his Polish colleagues. His contacts with Jerzy Maj and Edmund Przegaliński from the Institute of Pharmacology of the Polish Academy of Sciences in Kraków started in the mideighties. Jerzy Nowak from Łódź, Edmund Przegaliński and Włodzimierz Buczko from Białystok visited the Institute of Pharmacology and Toxicology in Bonn. Barbara Malinowska (B. M.) from Białystok spent 19 months in Bonn as a recipient of an Alexander von Humboldt Foundation fellowship. [However, her scientific cooperation with Prof. Göthert resulting in 13 joint publications occurred after her return to Białystok and during Prof. Göthert's 6-month stay in Białystok (split into several periods in 2006-2009) as a recipient of an Alexander von Humboldt Polish Honorary Research Fellowship]. Starting from 1992, Prof. Göthert regularly took part in all congresses of the Polish Pharmacological Society (PPS). In 1993 he participated in the symposium organized on the occasion of the 20th anniversary of the cooperation between Polish and German pharmacologists in Zakopane (Poland). Ten years later, he organized (together with Eberhard Schlicker, B. M. and Edmund Przegaliński) a symposium on the occasion of the 31st anniversary (Białowieża, Poland [3]) and in 2014 alone a minisymposium "Four Decades of Cooperation of Polish and German Pharmacologists" (Hannover, Germany [4]). He was the chairman of the German delegation of bilateral talks on cooperation in the field of medical sciences (Berlin and Bonn; Germany, 2000). Since 1994, Prof. Göthert was advisory editor of the Polish Journal of Pharmacology/Pharmacological Reports. W. Lason, the former editor-in-chief of this journal, wrote to B. M.: "I have not met a representative of another nation who was so sincerely interested in the development of Polish pharmacology and maintaining the high position of Pharmacological Reports. He was really proud of our modest achievements, he supported the journal with his manuscripts, sent congratulations and valuable suggestions".

In recognition of Prof. Göthert's activities in the field of German-Polish cooperation he was elected as a foreign member of the Polish Academy of Arts and Sciences (1997), and honoured by the honorary membership of the PPS (2001), the degree of "Dr. honoris causa" of the Medical Universities in
Białystok (2003) and Katowice (2004) and the honorary medal of the Institute of Pharmacology, Polish Academy of Sciences (1999).

Prof. Göthert's family placed words by the German poet Emanuel Geibel into the obituary: "There is something stronger than destiny. This is the courage with which one copes with destiny". These words perfectly illustrate the battle Prof. Göthert fought against Parkinson's disease over a time period of 15 years. During that time he published two reviews about serotonin in Pharmacological Reviews (with Klaus B. Fink) and in Pharmacological Reports "dedicated to the reconciliation, cooperation and friendship between Poles and Germans". He was a visiting professor in the department of B. M., publishing with her group three original papers and teaching her young co-workers by his own example that "Being a scientist is not only a profession. It is a lifestyle". He gave plenary lectures during the congress of the International Society of Serotonin Research (Montreal, 2010) and the 17th Congress of the PPS (Krynica Zdrój, 2010) and organized a minisymposium in Hannover (2014). In 2015 he took part in the 19th Congress of the PPS in Świnoujście. One year ago he wrote to B. M. that his dream was to take part in the 20th PPS congress that would be the summary of his efforts for scientific and political relationships between our countries. His disease did not allow him to participate in this congress, which took place 3 weeks before his death.

We remember Prof. Manfred Göthert as a constantly smiling man, an eternal optimist, determined in his views, kind, straightforward and spontaneous in dealing with other people, who did not care about maintaining a distance between him as a boss and colleagues. We lost not only a great man and scientist, but also a great protagonist of the German-Polish cooperation. Polish pharmacologists have lost a GREAT FRIEND.

Acknowledgements Open Access funding provided by Projekt DEAL.

Open Access This article is licensed under a Creative Commons Attribution 4.0 International License, which permits use, sharing, adaptation, distribution and reproduction in any medium or format, as long as you give appropriate credit to the original author(s) and the source, provide a link to the Creative Commons licence, and indicate if changes were made. The images or other third party material in this article are included in the article's Creative Commons licence, unless indicated otherwise in a credit line to the material. If material is not included in the article's Creative Commons licence and your intended use is not permitted by statutory regulation or exceeds the permitted use, you will need to obtain permission directly from the copyright holder. To view a copy of this licence, visit http://creativecommons.org/licenses/by/4.0/.

\section{References}

1. Göthert M. Life in movement as a scientist. In: Philippu A, editors. Geschichte und Wirken der pharmakologischen, klinisch-pharmakologischen und toxikologischen Institute im deutschprachigen 
Raum, vol 4-Autobiographien. Innsbruck: Berenkamp; 2014. p. 185-210.

2. Göthert M. Jestem niemieckim Europejczykiem. Medyk Białostocki. 2004; $1: 14$

3. Malinowska B, Göthert M, Przegaliński E, Schlicker E. Report on the German-Polish symposium "Thirty years of cooperation between German and Polish pharmacologists. New perspectives in the Common Europe". Pol J Pharmacol. 2003;55:807-10.
4. In: Program Minisymposium, Hannover, April 2, 2014. Pharmacol Rep. 2014;66:329.

Publisher's Note Springer Nature remains neutral with regard to jurisdictional claims in published maps and institutional affiliations. 